\title{
Leachate Treatment Using Up-Flow Anaerobic Sludge Blanket System
}

\author{
Mohd Baharudin Ridzuan ${ }^{1 *}$, Zawawi Daud ${ }^{1}$, Zulkifli Ahmad ${ }^{1}$, Ab Aziz Abd \\ Latiff $^{1}$, Halizah Awang ${ }^{2}$
}

${ }^{1}$ Faculty of Civil and Environmental Engineering, Universiti Tun Hussein Onn Malaysia, 86400 Parit Raja, Batu Pahat, Johor, Malaysia

${ }^{2}$ Faculty of Technical and Vocational Education, Universiti Tun Hussein Onn Malaysia, 86400 Parit Raja, Batu Pahat, Johor, Malaysia

Received 22 January 2018; accepted 4 March 2018, available online 1 May 2018

\begin{abstract}
Leachate is one of the major problems to overcome in managing the landfill. Low cost treatment, less maintenance and environmental friendly are the target on how to treat the leachate. This research focused on the effectiveness of Up-flow Anaerobic Sludge Blanket on leachate treatment. This study was carried out upon treatment of leachate by using Up-flow Anaerobic Sludge Blanket through reactor tank in lab-scale. Without a proper treatment, leachate will give a negative effect to the environment and become pollutant. This research is determining percentage nutrient removal on leachate. The leachate characteristic also been investigated. The main parameters evaluations are Biochemical Oxygen Demand (BOD), Chemical Oxygen Demand (COD), Total Suspended Solid (TSS), Total Nitrogen (TN) and Total Phosphorus (TP). Experiments were run in duration of 30 days were sample for test had been taken each 3 days. Results show that the capability of UASB in the removal several parameters. This UASB had a greater ability in removal of Total Phosphorus and TSS with $89 \%$ and $81 \%$ respectively. For COD, BOD and TN, the values are $74 \%, 64 \%$ and $50 \%$. Based on these results, it clearly shows that UASB capable to remove physical and chemical properties of leachate.
\end{abstract}

Keywords: Leachate; Up-flow Anaerobic Sludge Blanket

\section{Introduction}

Leachate is a liquid generated from landfill site and garbage lorry. Leachate composition is different depends on the age and type of the waste on the landfill. Leachate also a liquid consisting of moisture generated from landfill during the waste degradation process. When leachate is produced and moving inside the landfill, it pick up soluble, suspended or miscible materials removed from such waste. Leachate also produced from rain water that runs through the solid waste at the landfill site and garbage lorry. The rain had a polluted consequential contact with solid waste. When this highly contaminated leachate leaves landfill and reaches water resource, over time, it will cause surface water and ground water pollution. The contamination of waste will affect the human body and the environment.

Up-flow anaerobic sludge blanket (UASB) technology, normally referred to as UASB reactor, is a form of anaerobic digester that is used in the treatment of wastewater. The UASB reactor is a methanogenic (methane-producing) digester that evolved from the anaerobic clarigester. The treatment is suitable for conventional domestic wastewater or blackwater; centralised or decentralised wastewater treatment but not usually at household level, rather at community level.

\section{Hybrid up-Flow Anaerobic Sludge Blanket (HUASB) Reactor}

Agamuthu and Ali has operated a laboratory scale hybrid UASB reactor which is a combination of a UASB in the lower part and a filter in the upper part was used for the treatment of wastewater such as distillery spent wash [1]. The reactor was operated under ambient conditions for 380 days. Using anaerobically sewage sludge as a. seed, the startup of the reactor and the cultivation of active granular sludge was completed within three months period. They used scanning electron microscopic (SEM) in the observation of the granules which showed the presence of Mehtanonthrixlike bacteria as the dominant species [1].

Hybrid UASB reactor is a combination between UASB and anaerobic filter, UASB reactor has been successfully used to treat various of organic wastewaters such as the tapioca starch wastewater, brewery wastewater and more. The advantages of UASB process are no need to use support material and concentrated biological growth. The stable operation and successful performance of UASB system is dependent on the sludge cultivated with good settle ability high methanogenic activity and granular form maintenance of granular age is significant to improve organic conversion efficiency and 
suspended solid efficiency. Development of palletized sludge depends on the characteristics off the wastewater and on the seed, sludge used at the operator startup. Combination of IUASB and fluidized bed process will provide better performance due to a better contact between the wastewater and biomass.

\section{Matrerial \& Method}

This study was focused on the ability of Up-flow Anaerobic Sludge Blanket on treat the leachate. The sample of leachate where collected from Simpang Renggam Landfill, Simpang Renggam, Johor.

Sample. Raw leachate samples were collected from Simpang Renggam landfill, Johor. The samples were collected in plastic container. Upon collection, the leachate was stored at $4^{\circ} \mathrm{C}$ to minimize any further change that might occur in its physiochemical and biological properties until the experiments analyses were carried out.

Batch Reactors. The experiments been carried out in a lab-scaled constructed filter which consists of the model from plastic prospect is $10 \mathrm{~cm}$ diameter and 100 $\mathrm{cm}$ height which gave the total volume of tank is 1963.50 $\mathrm{cm}^{3} \approx 19.64 \mathrm{~m}^{3}$. On this filter contain leachate sludge as a blanket with $40 \mathrm{~cm}$ height, fine grain with $40 \mathrm{~cm}$ height and $3 \mathrm{~cm}$ zeolite at the top of filter as a media (Figure 1).

Metal Analysis. Raw leachate has poured into the influent bucket behind the constructed filter. Then the raw leachate is pumped onto bottom of constructed filter. The leachate going through the media and at the top of filter, the treated leachate has been stocking up before the treated supernatant leachate throughout from filter to the collection bucket. The flow of the pump is $0.1 \mathrm{ml} / \mathrm{min}$. So, the pump has been operated in one hour then the leachate had detention 47 hour in the filter. Progresses of tank been checked each 3 days in a month. Besides that, the parameter was tested are $\mathrm{pH}$, Biochemical Oxygen Demand (BOD), Chemical Oxygen Demand (COD), Total Suspended Solid (TSS), Total Nitrogen (TN) and Total Phosphorus (TP). Characteristic of Simpang Renggam landfill leachate and percentage of nutrient removal has been determined. All the parameters procedure based on standard method for the examination water and wastewater by American Public Health Association (APHA) and American Water Works Association (AWWA).

\section{Result \& Discussion}

Leachate characteristic. Table 1 shows the initial characteristic of raw leachate from Simpang Renggam landfill compared to the characteristic of typical landfill leachate, Bukit Tagar landfill and Taman Beringin landfill. The constituents in the leachate may vary depending on waste compositions and weather.

Some general observation has been made when comprising the Simpang Renggam landfill leachate with other Malaysian landfill leachate data and typical data. Leachate from Simpang Renggam landfill and Bukit Tagar Sanitary landfill has been different. Besides,
Simpang Renggam landfill and Taman Beringin landfill had slightly same on BOD characteristic were $253 \mathrm{mg} / \mathrm{L}$ and 560-1520 respectively.

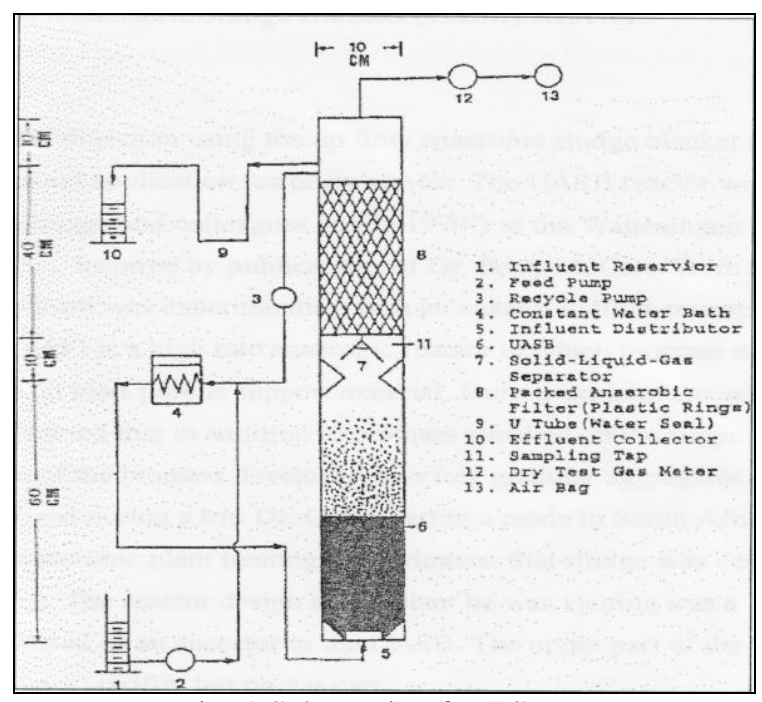

Fig. 1 Schematic of UASB reactor

Table 1 Numerically obtained maximum flame temperature for different fuel mass fraction and air temperature at constant strain rate $a_{2}=300 \mathrm{~s}^{-1}$ and adiabatic flame temperature for corresponding reaction.

\begin{tabular}{cccc}
$\begin{array}{c}\text { Fuel mass } \\
\text { fraction } \\
\left(\mathrm{Y}_{\mathrm{F}, 1}\right)\end{array}$ & $\begin{array}{c}\text { Tempera- } \\
\text { ture of hot } \\
\text { air } \mathrm{T}_{2}(\mathrm{~K})\end{array}$ & $\begin{array}{c}\text { Maximum } \\
\text { flame } \\
\text { tempera- } \\
\text { ture }(\mathrm{K})\end{array}$ & $\begin{array}{c}\text { Adiabatic } \\
\text { Flame } \\
\text { tempera- } \\
\text { ture }(\mathrm{K})\end{array}$ \\
\hline 0.1 & 1340 & 1880 & 1908 \\
0.3 & 1230 & 2364 & 2541 \\
0.5 & 1215 & 2627 & 2740 \\
0.8 & 1200 & 2735 & 2882 \\
\hline
\end{tabular}

Table 2: Comparisons on the composition of leachate from landfills

\begin{tabular}{|c|c|c|c|c|}
\hline Constituent* & ह & 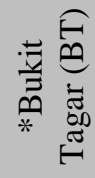 & 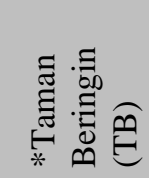 & 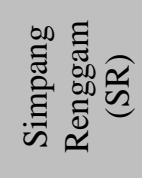 \\
\hline $\mathrm{BOD}_{5}(\mathrm{mg} / \mathrm{L})$ & 10,000 & 27000 & $560-1520$ & 253 \\
\hline COD (mg/L) & 18,000 & 59000 & $2050-5230$ & 14,640 \\
\hline TSS (mg/L) & 500 & - & - & 2,010 \\
\hline TN (mg/L) & 200 & - & - & 4,300 \\
\hline $\mathrm{TP}(\mathrm{mg} / \mathrm{L})$ & 30 & & - & 259 \\
\hline $\mathrm{pH}-$ & 6 & 6.6 & $8.07-8.5$ & 7.17 \\
\hline
\end{tabular}

* Source: [1]

Bukit Tagar Landfill are highest then SR and TB with $27,000 \mathrm{mg} / \mathrm{L}$ and the middle of the range are typical landfill, 10,000 mg/L. Based on series if decomposition phase of solid waste, this different due to the landfill age since the Bukit Tagar Landfill (3 year) is younger than Taman Beringin (closed since 2006) and Simpang Renggam landfill (opened before 2003). It can conclude that leachate generated at Simpang Renggam are phase III 
on degradation process, because leachate produced during phase III are characteristic by relatively low BOD values and low ratio of $\mathrm{BOD} / \mathrm{COD} ; 0.02<0.25$. In fact, the composition of phase III leachate (methanogenic phase) is characterized by neutral $\mathrm{pH}$ levels.

Known, COD is amount of organic compound (organic pollutant) on body water were generally organic compound found naturally in plant and animals. Therefore, the value COD, 14,6400 $\mathrm{mg} / \mathrm{L}$ are quite higher than Taman Beringin landfill eventhough both slightly same because the landfill located inside of palm-oil plantation that rich with organic compound.

Not as TSS, TN and TP were the nutrient on the Simpang Renggam landfill higher compared to the typical landfill. The value of TSS is higher than typical landfill because the Simpang Renggam landfill doesn't have proper channel and leachate collecting system. Therefore, the leachate had through the ground surface as a runoff. Meanwhile, TN and TP nutrient on Simpang Renggam landfill can be reaching up to thousand values compared to typical landfill were just a hundred values. It happened because the plantation is using fertilizer during fertilizing process. Where, ammonia is produced though the formation of fertilizers and chemicals. As a result, large amounts of fertilizer are present in agricultural runoff [2] and ammonia is made up to nitrogen and hydrogen. Eventhough leachate usually has high nitrogen and low phosphorus, because of ammonia also made up phosphorus, the phosphorus is higher than typical.

Percentage removal. Percentage removal is most important things in treatment analysis. Where, percentage removal can state that treatment is succeeding or not. Without percentage removal, we don't know whether the treatment is suitable for those pollutants.

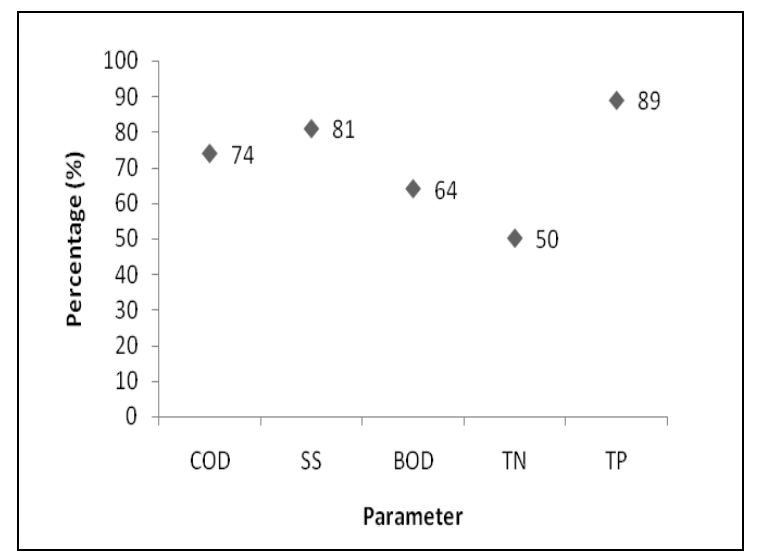

Fig. 2 Average Percentage Removal

Graph show average percentage removal of all parameters. The highest parameter removal is TP with average $89 \%$ removal. By the addition of Zeolite an improvement of the elimination of $\mathrm{P}$ for more than $50 \%$ from water containing more than $100 \mathrm{mg} / \mathrm{L} \mathrm{TP}$ can be achieved [6]. Because of that, this treatment succeeds in remove TP parameter.

Average of SS and COD percentage removal are $81 \%$ and $74 \%$ respectively. Where UASB is presently can remove the SS and COD. Then, only $64 \%$ can remove the BOD presently on body leachate.

The lowest removal is TN with average $50 \%$ removal. Zeolite is a promising material for the simultaneous removal of ammonium and phosphate from wastewater [3]. However, in this study TN can't remove as much as TP.

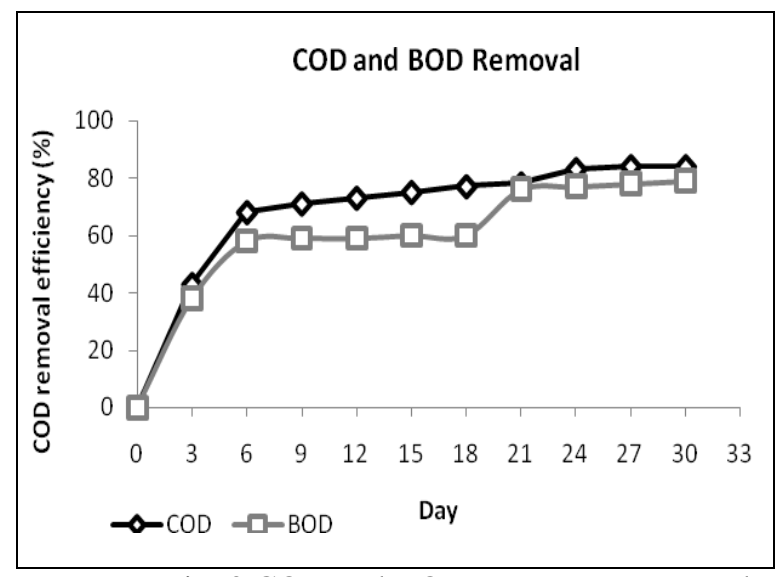

Fig. 3 COD and BOD Percentage removal

This graph showed COD removal rate is quite good in first week, on day-3 and day- 6. On day-9 and further, still increase although the rate are quite constant. COD removal efficiencies in the range of $60-95 \%$ can be achieved depending on the process conditions [4], proven that UASB can remove COD, beside the zeolite also can help in process of removal. Therefore, this experiment succeed in removing average $74 \%$ COD where the raw concentration is $14640 \mathrm{mg} / \mathrm{L}$ until day-30 decrease to 2,330 mg/L.

Based on average $64 \%$ removal of BOD, it does can conclude that the reactor can remove BOD on leachate. From $253 \mathrm{mg} / \mathrm{L}$ concentration of BOD decrease to 53 $\mathrm{mg} / \mathrm{L}$ strictly to standard B of Effluent Standard Discharge by DOE, $50 \mathrm{mg} / \mathrm{L}$. It's because, BOD for leachate at Simpang Renggam is very low compared to the typical landfill. Therefore, to remove BOD on leachate it may be doesn't take a long time.

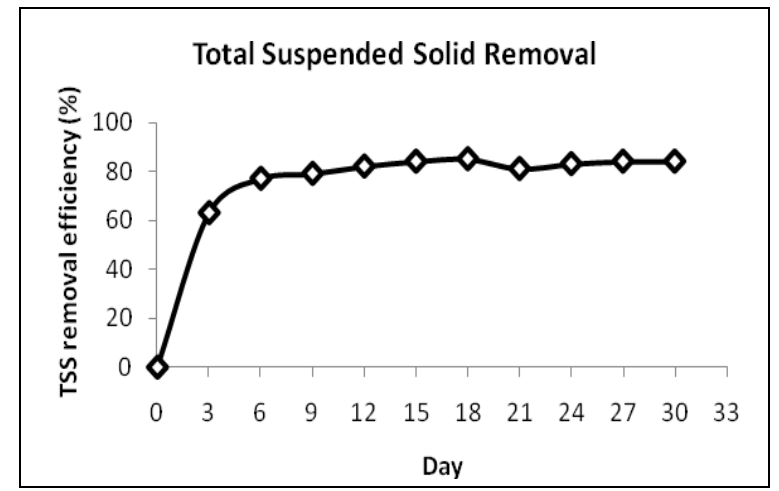

Fig. 4 TSS Percentage Removal

From 2,010 mg/L of TSS on leachate, this reactor can remove that TSS to $230 \mathrm{mg} / \mathrm{L}$. Therefore, the average percentage of TSS removal is $81 \%$. TSS and VSS 
removal efficiencies of up to $95 \%$ have been achieved when HRT $>6$ h [5].

However, on day-18 and day-21, the TSS concentration increases from $300 \mathrm{mg} / \mathrm{L}$ to $380 \mathrm{mg} / \mathrm{L}$, where $4 \%$ decreasing at day period. It's probably happened because at that day, the effluent become dark than before result from the sample taken are from different bottle. Although not so obvious, but it still has some effect on the result.

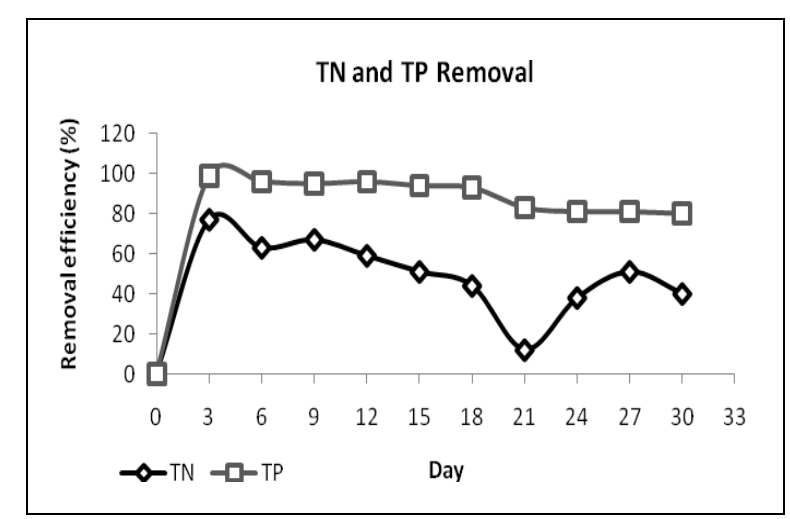

Fig. $5 \mathrm{TN}$ and TP Percentage removal

Based on figure 5, average total phosphorus removal is $89 \%$. From raw, have $259 \mathrm{mg} / \mathrm{L}$ TP nutrient on leachate. But at day-3, the TP decrease mostly to 0 with $2 \mathrm{mg} / \mathrm{L}$ (99\% removal). However after that, TP nutrient become increasing little by little to $53 \mathrm{mg} / \mathrm{L}$. There are less previous studies about TP removal efficiency by UASB, however as discussion at average percentage removal above, zeolite can remove TP on body leachate.

Generally, TN shows that removal is less succeeding. Average percentage of total nitrogen removal is $50 \%$. At a first, the TN can remove to $980 \mathrm{mg} / \mathrm{L}$ from $4300 \mathrm{mg} / \mathrm{L}$ where it can remove $77 \%$ TN. However, after that, the TN percentage graph become fluctuates and at day-30 there is $2590 \mathrm{mg} \mathrm{TN} / \mathrm{L}$ concentration ( $40 \%$ removal).

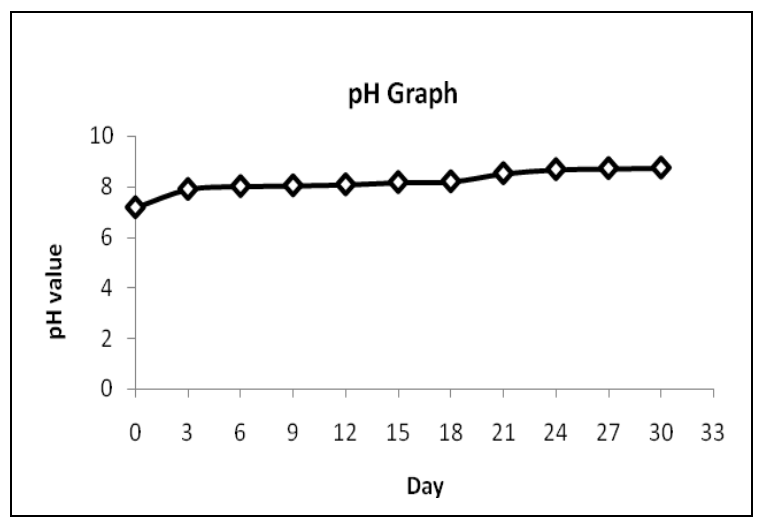

Fig. 6 pH value

$\mathrm{pH}$ graph shows the increasing of $\mathrm{pH}$ value every 3 days for a month. Where $\mathrm{pH}$ value of raw leachate is 7.17 and end of a month the $\mathrm{pH}$ value become 8.73 . Based on $\mathrm{pH}$ range, $6.5-8.5$ are neutral. Hence, the from $\mathrm{pH}$ range, can conclude that raw leachate are neutral until day-18 with $\mathrm{pH}$ value 8.19 . Starting day-21 the leachate is acidic with $\mathrm{pH}$ value 8.51 until day-30. However, the leachate should be controlled to maintain the $\mathrm{pH}$ in neutral condition. Sodium chloride is good nutrient to add on leachate as a $\mathrm{pH}$ control.

\section{Conclusions}

There were several conclusions can be drawn in this research. Up-flow Anaerobic Sludge Blanket had great ability in removing Total Phosphorus and Total Suspended Solid in leachate. After 30 days of treatment, the reactor gives the highest removal efficiency of TP and TSS which were $89 \%$ and $81 \%$, respectively.

Leachate treatment by using Up-flow Anaerobic Sludge Blanket had contributed in removal of COD (average $74 \%$ removal). At the end of 30 days of treatment, the treatment system had ability to reduce those parameters in leachate. Besides, the UASB succeed in remove average $64 \%$ BOD on the leachate.

However, the total nitrogen shown the removal is less succeeds only $50 \%$ removal. It's mean the leachate treatment by using Up-flow Anaerobic Sludge Blanket is not really suitable to remove TN nutrient. Based on value of nutrient on day-30, there is not even one of them reaching Effluent Standard Discharge value for standard B. However, all those value can achieve standard B if time further extended. Especially for BOD because value day-30 BOD is $53 \mathrm{mg} / \mathrm{L}$.

\section{References}

[1] Agamuthu, P and Said Nasser Ali, Physico-Chemical Treatment of Bukit Tagar Sanitary Landfill Leachate using P-Floc775 and Ferric Cloride, Malaysian Journal of Science, Vol. 28, No. 02, 2009, pp. 187195.

[2] Cowman, J, Total Nitrogen Removal in a Completey Mixed Mambrane Biofilm Reactor for Nitrification and Denitrification, Northwestern University, 2004.

[3] Kim, T.H, Nam, Y.K and Lee, M, Nitrogen and Phosphorus Removal from Livestock Wastewater by Zeolite Ion Exchange and Ionizing Radiation,Journal of Science, Engineering and Technology, Vol. 54, 2009, pp. 9-13

[4] Driessen, W.J.B.M, Tielbaard, M.H, and Vereijken, T.L.F.M, Experience on Anaerobic Treatment of Distillery Effluent With The UASB Process, Journal of Water, Science Technology, Vol. 30, No. 12, 1994, pp. 193-201.

[5] Lucas Seghezzo, et. all., The Effect of Sludge discharge and Upflow Velocity on the Removal of Suspended Solid in a UASB Reactor Treating Settled Sewage at Moderate Temperature, Journal of Water Science and Technology, 2006, pp.367-372

[6] J. Hrenovic, et. all., Use of Natural Zeolite to Upgrade Activated Sludge Process, Journal of Food Technology and Biotechno;ogy, Vol. 41, No. 2, 2003, pp. 157-165. 